\title{
IgM Antiavian Antibodies in Sera From Patients With Pigeon Breeder's Disease
}

\author{
Erasmo Martínez-Cordero, ${ }^{1,3 *}$ Diana E. Aguilar León, ${ }^{1}$ and Virginia Novelo Retana ${ }^{2}$ \\ ${ }^{1}$ National Institute of Respiratory Diseases (INER), México City, México \\ ${ }^{2}$ General Hospital of México, México City, México \\ ${ }^{3}$ National Medical Center "20 de Noviembre," ISSSIE, México City, México
}

\begin{abstract}
The authors' objective was to study the presence of IgM antiavian antibodies in sera from patients with pigeon breeder's disease. We studied 93 patients with interstitial lung disease admitted for the assessment of pigeon breeder's disease. Eighty sera from healthy donors with no history of bird contact and 47 asymptomatic pigeon breeders were included as controls. The presence of $\operatorname{lgM}, \lg G$, and $\lg A$ antiavian antibodies was detected by ELISA and Western blot using avian-pooled serum antigen. Fifty-three patients were classified as having definite pigeon breeder's disease, whereas 40 did not fulfill these diagnostic criteria. The levels of IgM antiavian-antibodies in pigeon breeder's disease by ELISA exceeded both the values of healthy subjects with no history of avian contact $\left(P=2.5 \times 10^{-8}\right)$ and the results of asymptomatic breeders $(P=0.03)$. Positive IgA antiavian antibodies were the most frequent abnormalities in pigeon
\end{abstract}

breeder's disease showing values over the reference levels of control groups that reach significant statistical differences. Both precipitin-positive and -negative samples demonstrated IgM reactivity. IgM antiavian antibodies were confirmed by Western blot. A relationship of IgM positive tests with a recent history of avian antigen exposure and acute disease was found. Additionally, the positive IgM group included patients having subacute and chronic lung disease. Antiavian antibodies have previously been considered of minor significance in hypersensitivity pneumonitis; nevertheless, recent studies support their use in clinical diagnosis. Although no specific laboratory tests can confirm the diagnosis in pigeon breeder's disease, IgM antiavian antibodies may be useful for detecting recent antigen exposure and the acute stage of the disease. J. Clin. Lab. Anal. 14:201-207, 2000. (c) 2000 Wiley-Liss, Inc.

Key words: hypersensitivity pneumonitis; bird; immune response; immunoglobulins

\section{INTRODUCTION}

Hypersensitivity pneumonitis indicates a group of inflammatory disorders characterized by a dominant interstitial pulmonary injury, which appears after the exposure of a diversity of extrinsic antigens. Pigeon breeder's disease (PBD) is one of the most frequent clinical entities within the hypersensitivity pneumonitis group in which the corresponding antigens belong to avian products (1). In this sense, feathers, drooping, and/or serum components from pigeon origin have been broadly studied as the possible trigger factors related to the appearance of the characteristic inflammatory reaction in the lung.

The accurate diagnosis of PBD usually depends upon various clinical, serological, physiological, radiological, and pathological findings which have a relevant value, particularly for the differential diagnosis to other interstitial lung disorders, as well as for a follow-up of the disease and the analysis of prognosis.

Through laboratory testing, one of the most relevant changes in PBD is the presence of circulating antiavian antibodies (AA), which have been extensively studied. Initial studies in regard to precipitating AA tests suggested a loss of clinical utility for the diagnosis of PBD and even for their differentiation from the wide group of interstitial lung disorders. But further evidence from several groups has supported the hypothesis that quantitation and the analysis of specific isotypes and immunoglobulin subclasses of serum AA, or their detection in bronchoalveolar lavage and even in salivary secretion, could be useful as predictive and specific hallmarks of the disease $(2,3)$.

The study of $\operatorname{IgG}$ and IgAAA and the search for high titers of these serologic abnormalities has been useful for differen-

Grant sponsor: National Council of Science and Technology (Mexico); Grant numbers D111-903735 and F643-M9406.

*Correspondence to: Dr. Erasmo Martínez-Cordero, Unidad de Investigación, Instituto Nacional de Enfermedades Respiratorias, INER. Calzada de Tlalpan 4502, México, D, F, 14080, México.

Received 3 February 2000; Accepted 4 April 2000 
tial diagnosis, particularly the distinction between PBD and other interstitial lung disorders. Indeed, positive and high IgG and IgA AA levels seem to separate PBD from healthy contacts. Also a correlation with the clinical stage of the disease including their exacerbation $(4,5)$ has been reported.

Because the clinical and pathological significance of $\operatorname{IgM}$, which characterizes the primary immune response, has scarcely been examined in hypersensitivity pneumonitis (68 ), the aim of the present study was to assess the presence of IgM AA in patients with PBD.

\section{MATERIALS AND METHODS}

We studied sera from 93 patients with interstitial lung diseases ( 83 females and 10 males; mean age 37.8 years). The duration of the disease ranged from 2 months to 18 years (mean 7.4 years). All patients were referred to our laboratory for the diagnostic study of PBD. The differential diagnosis was made according to previous reports $(1,9)$. The presence of PBD was confirmed by clinical, immunological, functional, and histopathological criteria, and by x-ray abnormalities compatible with this entity $(1,9)$ after the analysis of their clinical records.

Because the interest in the present study was to search the significance of $\operatorname{IgM}$ antibody response, we conducted the analysis in all consecutive patients in which the routine screening for precipitating AA or IgGAA by ELISA were performed according to earlier studies $(1,10)$. Eighty sera from healthy blood donors with no history of bird contact were also analyzed. These volunteers ( 71 females, 9 males; mean age 36.7 years) were previously studied in order to exclude any pulmonary disease. All of them showed normal pulmonary function tests and negative clinical and x-ray changes, suggestive of lung impairment. Forty-seven sera from exposed asymptomatic pigeon breeders (43 females, 4 males; mean age 38.2 years) selected from healthy blood donors and from members of a local pigeon-racing club with a history of antigen exposure comparable with the PBD group, were also studied. These subjects revealed negative data of pulmonary diseases by history and physical examination.

Precipitating AA tests were made according to previous studies (11). In brief, avian-pooled serum antigen from 100 pigeons were collected and maintained in aliquots at $-80^{\circ} \mathrm{C}$, until their use. Small Petri dishes were prepared with $1 \%$ agarose (Bio-Rad Richmond, CA) in phosphate buffer saline (PBS) (0.01 M, pH 7.4). A cutter was used to get a central well and 6 peripheral wells (4 $\mathrm{mm}$ in diameter) at a distance of $6 \mathrm{~mm}$ from the center. We added increased concentration of antigen, as well as serial dilution from patients and control sera. Central wells were filled with tested serum using undiluted and 1:64 to 1:1240 dilution, whereas peripheral wells were filled using undiluted sample and serial antigen dilution ranging from 1:64 to 1:1,240. The plates were placed in a moist chamber, then covered and allowed to remain at room temperature for $48 \mathrm{hr}$. After washing the plates with sodium citrate $(0.15 \mathrm{M})$, the gels were stained with Coomassie blue R250 (0.2\%) in methanol-acetic acid solution. Each test always included positive and negative reference sera. The presence of AA was recorded as positive after the analysis of intensity and number of diffusion bands, as previously described (11).

IgM, IgG, and IgA AA were measured by ELISA using optimal conditions selected after the standardization of these tests in our laboratory (1). Briefly, microtiter plates (Maxisorb, Nunc, Roskilde, Denmark) were coated with $100 \mu \mathrm{l}$ of $12 \mu \mathrm{g} /$ $\mathrm{ml}$ of avian-pooled serum in bicarbonate-carbonate buffer (0.05 M, pH 9.6). After overnight incubation, the wells were washed 5 times with PBS-Tween-20 (0.05\%) and quenched with $1 \%$ bovine serum albumin fraction V (Sigma Co., St. Louis, MO). The patients and control sera were added for 1 hr at $37^{\circ} \mathrm{C}$. Binding of AA to the antigen coated wells was detected with optimal dilution of peroxidase label $\mathrm{F}\left(\mathrm{ab}^{\prime}\right)_{2}$ fragment of antihuman IgM, IgG, or IgA (Sigma Co.). The substrate orthophenylenediamine (OPD) was prepared in citrate buffer $(0.1 \mathrm{M}, \mathrm{pH} 5)$ containing hydrogen peroxide and the reaction was stopped after $15 \mathrm{~min}$ at room temperature with $50 \mu \mathrm{l}$ of $2.5 \mathrm{~N}$ of sulfuric acid. Absorbance (492 nm) was read in a micro ELISA minireader (Labsystem) and the results were reported in optical density (OD) (492 nm) units (U). Each serum was assayed in duplicate. Positive and negative reference sera were included in each plate.

In order to confirm the presence of IgM, we studied the levels of AA by ELISA after the treatment with 2-mercaptoethanol. In brief, $100 \mu \mathrm{l}$ of serum were incubated with 2 $\times 10^{-3}$ 2-mercaptoethanol for $15 \mathrm{~min}$ at $37^{\circ} \mathrm{C}$ in agitation as previously described (12). The samples were added to the microtiter plates previously coated with avian-pooled serum for their $\operatorname{IgM}, \operatorname{IgG}$, and $\operatorname{IgA}$ AA tests.

The presence of IgM, IgG, and IgA AA were also studied by Western blot. Briefly, avian-pooled serum antigen $(12 \mu \mathrm{g} /$ $\mathrm{ml}$ ) was separated in a SDS-PAGE $(7.5 \%)$, under reducing conditions, according to the Laemmli technique (13). The protein was transferred into nitrocellulose sheets and quenched with PBS containing $1 \%$ bovine serum albumin fraction $\mathrm{V}$ (Sigma Co.) (14).

The patients and control sera were appropriately diluted. After overnight incubation of the samples, each nitrocellulose trip was washed 5 times with PBS-Tween-20 (0.1\%) and the reaction of AA was detected by adding an optimal dilution of peroxidase labeled $\mathrm{F}\left(\mathrm{ab}^{\prime}\right)_{2}$ fragment of antihuman $\operatorname{IgM}$, IgG, or IgA (Sigma Co.). The substrate 4-cloronaphtol (30 $\mathrm{mg})$ was prepared in methanol $(10 \mathrm{ml})$ and PBS $(50 \mathrm{ml})$ and after the reaction ended, we analyzed the appearance of specific binding of antibodies, which was compared to molecular weight markers (BRL-Gibco).

The specificity of ELISA and Western blot for the detection of AA was made as previously described (15) in order to exclude the possible cross-reactivity of avian-pooled sera 
antigen with human sera. For this objective, we used untreated patient sera and samples incubated with avian-pooled sera antigen and serum from patients previously combined with hypogammaglobulinemic human sera.

The results of AA in PBD detected by ELISA were compared to those AA levels obtained from healthy control subjects with no bird exposure (mean \pm SD, $\operatorname{IgM} 0.0732 \pm 0.0305$ ODU, $\operatorname{IgG} 0.1055 \pm 0.0661$ ODU and $\operatorname{IgA} 0.0540 \pm 0.0268$ ODU); asymptomatic pigeon breeders (mean $\pm \mathrm{SD}, \operatorname{IgM} 0.169$ $\pm 0.144 \mathrm{ODU}, \operatorname{IgG} 0.633 \pm 0.273 \mathrm{ODU}$ and $\operatorname{IgA} 0.421 \pm 0.410$ ODU), and also from interstitial lung disease patients excluding PBD (mean \pm SD, IgM $0.091 \pm 0.093$ ODU, IgG $0.132 \pm$ 0.055 ODU and IgA $0.101 \pm 0.090 \mathrm{ODU}$ ). The reference limit was established as the mean $+2 \mathrm{SD}$. The statistical analysis was made using the student's $t$-test (Statistica V. 4.3).

\section{RESULTS}

Of the group of patients admitted for their lung disease assessment, 53 met the diagnosis of definite PBD according to their clinical, functional, and pathological manifestations $(1,9)$. Forty patients with interstitial lung disease did not fulfill PBD criteria. Precipitating tests for avian antibodies by Ochterlony were positive in 34 of these PBD patients (64.1\%), whereas only 4 positive precipitating tests (10\%) were detected in the interstitial lung patients with no PBD.

The serological findings in the different groups assessed by ELISA, including healthy controls with no avian exposure, interstitial lung patients excluding PBD, asymptomatic pigeon breeders, and those detected in the definite PBD group showed several interesting differences regarding $\operatorname{IgM}, \mathrm{IgG}$, and IgA AA (Fig. 1).

The analysis of IgM AA revealed that their levels were higher in PBD than in all comparison groups. The evaluation of these antibodies showed that AA levels in PBD differed not only from healthy controls and interstitial lung patients with no PBD, but also from asymptomatic breeders. Statistical analyses among these groups reached significant differences $\left(P=2.5 \times 10^{-8}, 0.002\right.$ and 0.03 respectively). Twenty-four of 53 PBD patients (45.2\%) have IgM AA levels over the mean
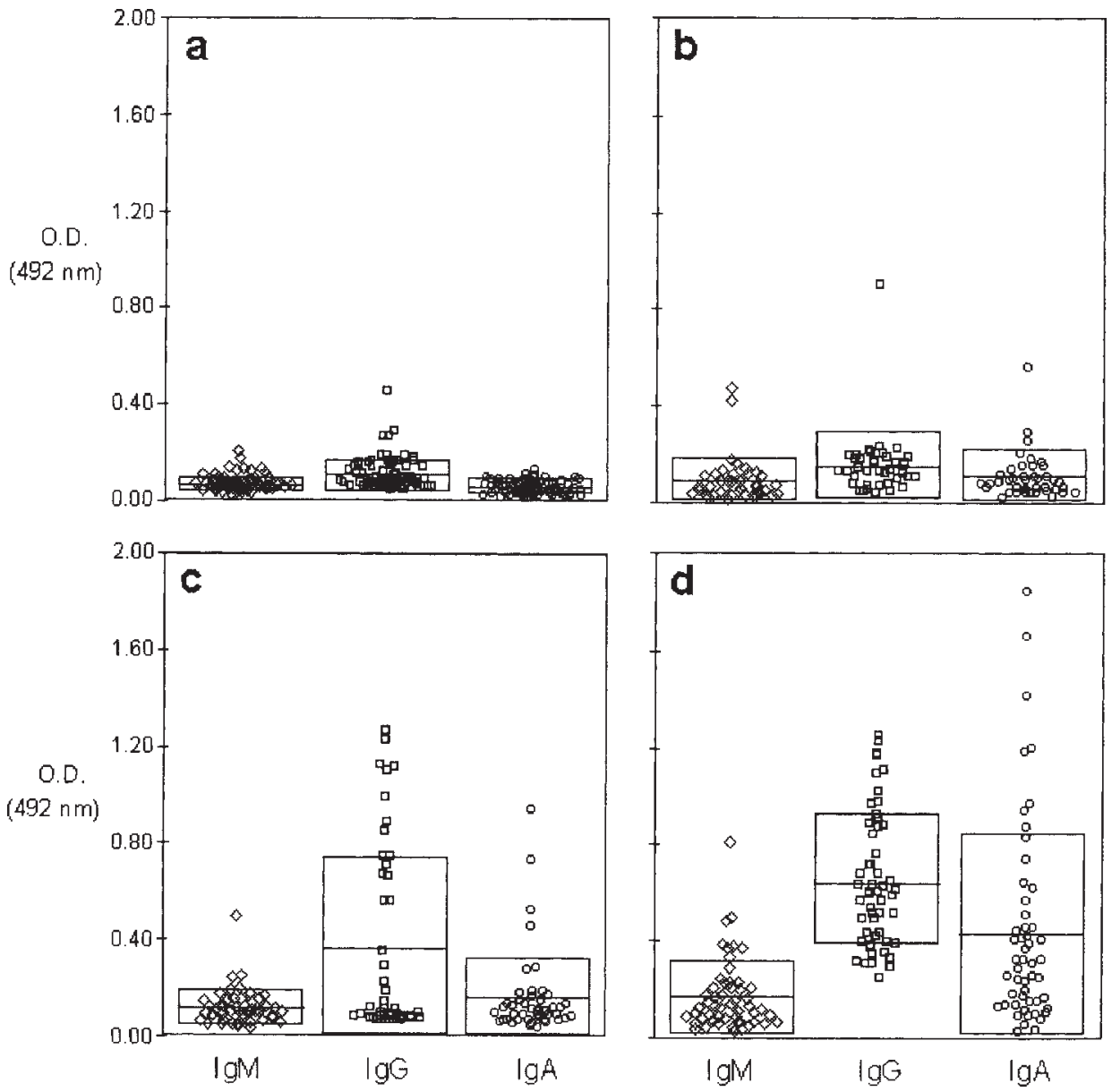

Fig. 1. Comparison of $\operatorname{IgM}, \operatorname{IgG}$, and $\operatorname{IgA}$ antiavian antibodies detected by ELISA among: a, healthy controls with no avian exposure; $\mathbf{b}$, patients with interstitial lung abnormalities excluding pigeon breeder's disease; c, asymptomatic pigeon breeders; and $\mathbf{d}$, definite pigeon breeder's disease patients. Horizontal lines represent the mean \pm SD of OD units in each group. 
+2 SD of healthy no exposed controls, whereas 9 of 53 PBD sera $(16.9 \%)$ showed IgMAA titers above the reference limit detected both in interstitial lung patients excluding PBD and in asymptomatic breeders.

The presence of precipitating tests by Ouchterlony occurred in 18 of those 24 PBD samples (75\%) showing positive IgM $\mathrm{AA}$, whereas no precipitating antibodies were detected in 7 positive IgM AA sera from the interstitial lung disease group with no PBD (Table 1). We confirmed that although these last patients did not present definite PBD after the analysis of their clinical records, they were classified as having chronic hypersensitivity pneumonitis. It was also noted that IgM AA values in interstitial lung patients excluding PBD, healthy controls, and asymptomatic breeders did not reveal significant differences.

In regard to IgG AA, higher values were found in $\mathrm{PBD}$ samples showing statistical significant differences in contrast to those values in interstitial lung patients excluding PBD and healthy controls with no avian exposure $\left(P=1.13 \times 10^{-19}\right.$ and $4.98 \times 10^{-22}$ respectively). The comparison with asymp- tomatic breeders also revealed significant high values in the $\operatorname{PBD}$ group $\left(P=4.01 \times 10^{-5}\right)$. Although most PBD sera demonstrated IgG AA levels over the mean +2 SD of healthy controls and also above the reference values of interstitial lung patients excluding PBD, less definite PBD samples revealed IgG AA results that exceeded the limit levels of asymptomatic breeders.

Positive tests for IgA AA were the most frequent abnormalities in PBD and these results by ELISA differed from all comparison groups. The values of IgA were higher in PBD than in healthy controls and interstitial lung patients excluding PBD $\left(P=2.7 \times 10^{-13}\right.$ and $3.7 \times 10^{-6}$ respectively $)$. These results in PBD also exceeded the values of asymptomatic pigeon breeders $\left(P=5.6 \times 10^{-5}\right)$. The levels of IgA AA tested were over the mean $+2 \mathrm{SD}$ of healthy controls in 45 of 53 PBD patients (84.9\%). Twenty-seven sera (50.9\%) demonstrated $\operatorname{IgA}$ levels over the reference limit of interstitial lung disease patients with no PBD and 13 of the 53 PBD (24.5\%) samples revealed IgA AA levels above the mean $+2 \mathrm{SD}$ of asymptomatic pigeon breeders.

TABLE 1. Clinical and serologic findings in patients with interstitial lung disease showing positive IgM AA tests ${ }^{\mathrm{a}}$

\begin{tabular}{|c|c|c|c|c|c|c|c|c|}
\hline Patient & $\begin{array}{l}\text { Age } \\
\text { (years) } \\
\text { /sex } \\
\end{array}$ & $\begin{array}{c}\text { Definite } \\
\text { diagnosis }\end{array}$ & $\begin{array}{c}\text { Disease } \\
\text { classification }\end{array}$ & $\begin{array}{c}\text { Evolution } \\
\text { (months or years) }\end{array}$ & $\begin{array}{c}\text { Precipitating } \\
\text { tests } \\
\text { (ouchterlony) }\end{array}$ & IgM-AA & $\begin{array}{c}\text { ELISA tests } \\
\text { IgG-AA } \\
\text { ODU (492 nm) }\end{array}$ & IgA-AA \\
\hline CJS & $29 / \mathrm{F}$ & PBD & Chronic & $2.5 \mathrm{y}$ & Positive, 2 & 0.160 & 1.087 & 0.250 \\
\hline $\mathrm{CHF}$ & $45 / \mathrm{F}$ & PBD & Subacute & $1 \mathrm{y}$ & Positive, 1 & 0.230 & 0.668 & 0.247 \\
\hline DME & $33 / \mathrm{F}$ & PBD & Acute & $3 \mathrm{~m}$ & Positive, 1 & 0.805 & 1.097 & 0.409 \\
\hline EJM & $51 / \mathrm{F}$ & PBD & Chronic & $2 y$ & Positive, 1 & 0.386 & 1.216 & 1.188 \\
\hline GQS & $40 / \mathrm{F}$ & PBD & Acute & $7 \mathrm{~m}$ & Positive, 1 & 0.480 & 1.1580 & 1.645 \\
\hline GHH & $67 / F$ & PBD & Chronic & $10 \mathrm{y}$ & Positive, 2 & 0.173 & 0.712 & 0.452 \\
\hline GPA & $43 / \mathrm{M}$ & PBD & Chronic & $5 \mathrm{y}$ & Positive, 2 & 0.142 & 1.274 & 1.860 \\
\hline HER & $53 / \mathrm{M}$ & PBD & Chronic & $7 y$ & Positive, 1 & 0.155 & 0.912 & 0.194 \\
\hline HRE & $74 / \mathrm{F}$ & PBD & Chronic & $5 y$ & Positive, 1 & 0.210 & 0.964 & 1.177 \\
\hline LJF & $35 / \mathrm{M}$ & PBD & Acute & $3 \mathrm{~m}$ & Positive, 2 & 0.232 & 0.864 & 0.501 \\
\hline MVM & $61 / \mathrm{F}$ & PBD & Subacute & $1.5 \mathrm{y}$ & Positive, 2 & 0.136 & 0.671 & 0.119 \\
\hline MNP & $52 / \mathrm{F}$ & PBD & Chronic & $4 y$ & Positive, 1 & 0.335 & 0.642 & 0.819 \\
\hline PLF & $26 / \mathrm{M}$ & PBD & Chronic & $3 y$ & Positive, 1 & 0.210 & 0.751 & 0.149 \\
\hline PFA & $35 / \mathrm{M}$ & PBD & Acute & $3 \mathrm{~m}$ & Positive, 2 & 0.198 & 0.595 & 0.107 \\
\hline PSH & $29 / \mathrm{F}$ & PBD & Subacute & $1 \mathrm{y}$ & Positive, 2 & 0.229 & 1.165 & 0.314 \\
\hline REE & $42 / \mathrm{F}$ & PBD & Chronic & $3.5 \mathrm{y}$ & Positive, 1 & 0.203 & 0.627 & 0.381 \\
\hline $\mathrm{RMM}$ & $49 / \mathrm{F}$ & PBD & Subacute & $1 \mathrm{y}$ & Positive, 1 & 0.243 & 0.486 & 0.436 \\
\hline SMR & $57 / \mathrm{F}$ & PBD & Acute & $7 \mathrm{~m}$ & Positive, 1 & 0.149 & 0.873 & 0.743 \\
\hline AMG & $67 / \mathrm{F}$ & PBD & Subacute & $1 \mathrm{y}$ & Negative & 0.380 & 0.304 & 0.170 \\
\hline HRA & $30 / \mathrm{F}$ & PBD & Acute & $2 \mathrm{~m}$ & Negative & 0.477 & 0.189 & 0.101 \\
\hline HPE & $58 / \mathrm{F}$ & PBD & Acute & $5 \mathrm{~m}$ & Negative & 0.494 & 0.381 & 1.390 \\
\hline MSS & $30 / \mathrm{F}$ & PBD & Acute & $8 \mathrm{~m}$ & Negative & 0.368 & 0.512 & 0.613 \\
\hline SHS & $51 / \mathrm{F}$ & PBD & Acute & $6 \mathrm{~m}$ & Negative & 0.366 & 0.375 & 0.929 \\
\hline TMH & $52 / \mathrm{F}$ & PBD & Acute & $4 \mathrm{~m}$ & Negative & 0.291 & 0.607 & 0.232 \\
\hline AME & $39 / \mathrm{F}$ & CHP & Chronic & $8.5 \mathrm{y}$ & Negative & 0.427 & 0.201 & 0.203 \\
\hline ARM & $50 / \mathrm{F}$ & CHP & Chronic & $11 \mathrm{y}$ & Negative & 0.179 & 0.290 & 0.314 \\
\hline BJL & $70 / \mathrm{F}$ & CHP & Chronic & $16 \mathrm{y}$ & Negative & 0.139 & 0.126 & 0.098 \\
\hline FSA & $46 / \mathrm{F}$ & CHP & Chronic & $13 \mathrm{y}$ & Negative & 0.180 & 0.246 & 0.251 \\
\hline MGA & $32 / \mathrm{M}$ & CHP & Chronic & $8 \mathrm{y}$ & Negative & 0.135 & 0.119 & 0.039 \\
\hline MCC & $49 / \mathrm{F}$ & CHP & Chronic & $6 y$ & Negative & 0.164 & 0.126 & 0.038 \\
\hline RCA & $68 / \mathrm{M}$ & CHP & Chronic & $5.5 \mathrm{y}$ & Negative & 0.182 & 0.190 & 0.810 \\
\hline
\end{tabular}

${ }^{a} \mathrm{ODU}$, optical density units; PBD, pigeon breeder's disease; CHP, chronic hypersensitivity pneumonitis; Positive, 1 or 2, gel diffusion precipitating bands; Acute, less than one year of evolution; Subacute, 1 to 1.9 years of evolution; Chronic, more than 2 years of evolution. Reference AA values in healthy donors with no history of bird exposure (mean +2 SD IgM 0.134, IgG 0.237 , and IgA 0.107 ODU) and asymptomatic pigeon breeders (mean +2 SD IgM 0.457, IgG 1.179, and IgA 1.241 ODU). 
The simultaneous appearance of different antibodies was common in PBD sera. The most frequent association was of high IgM AA with elevated IgA AA values. None of the samples in the interstitial lung group with no PBD showed two or more concurrent positive AA tests.

In order to confirm the presence of $\operatorname{IgM}$, sera from PBD patients were treated with 2-mercaptoethanol (12) and then tested for AA by ELISA. The titers of AA demonstrated a drop in the levels of IgM AA but not in IgG or IgA AA after the same treatment. The tests used to determine the specificity of ELISA revealed a decrease in AA over $95 \%$ after the incubation with avian-pooled sera in comparison to their untreated samples. No changes were found using hypogammaglobulinemic control sera in comparison with their respective untreated samples.

The presence of IgM was confirmed by Western blot using avian-pooled serum antigen. Although there were several positive AA bands showing reactivity to a variety of different molecular weight components, a constant binding against a 58-kDa polypeptide was detected. Positive tests of IgM by Western blot occurred in all PBD sera that showed high IgM AA titers by ELISA and similar results were also detected in IgM positive samples from asymptomatic pigeon breeders (Fig. 2). The sera of healthy subjects with no history of avian contact did not show a specific IgM AA reactivity by Western blot.

After clinical analysis, it was evident that $\operatorname{IgM}$ antibodies occurred not only in patients with recent history of avian exposure and an acute stage of the disease (characterized by

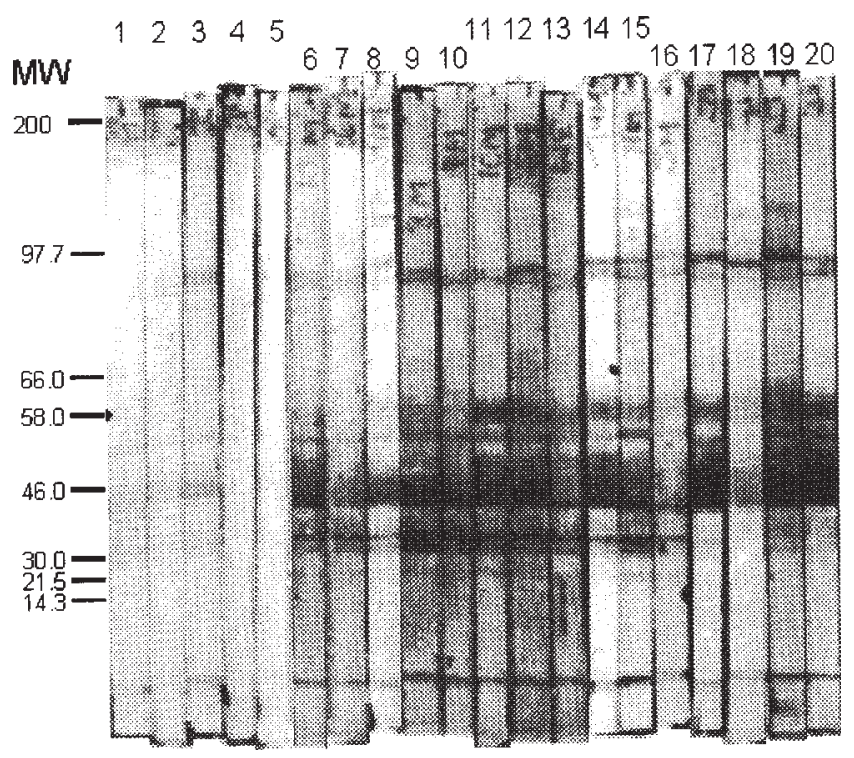

Fig. 2. Analysis of IgM reactivity by Western blot in pigeon breeder's disease and controls. Lanes 1-5, healthy controls; lanes 6-10, IgMAA negative patients; lanes 11-15, pigeon breeder's disease patients with positive IgM AA; lanes 16-20, asymptomatic pigeon breeders with positive IgMAA tests. MW represents molecular weight markers. The arrow indicates the 58$\mathrm{kDa}$ reactivity. bilateral rales, infiltrates on chest x-rays, hypoxemia, and low FVC and $\mathrm{DLCO}_{2}$ values according to previous studies (15)), but also in patients having subacute and chronic pulmonary disease (see Table 1).

Clinical, radiographic findings and serological abnormalities, as well as smoking habits, did not reveal any additional significant relationship with the results of circulating IgM AA tests.

\section{DISCUSSION}

PBD is characterized by diffuse interstitial lung inflammation, in which much evidence supports the hypothesis that airway antigen exposure may initiate the appearance of different immunological changes, including circulating AA.

The quantitation of antibody response against avian antigens, as well as the analysis of specific isotypes and immunoglobulin subclasses have recently suggested that high antibody levels and certain isotypes of AA may be useful as predictive and specific markers for PBD (3-5). Indeed, high titers of $\mathrm{IgG}$ and $\mathrm{IgAAA}$ reactivity against pigeon serum were found to be significantly associated with PBD and symptomatic breeders compared with asymptomatic relatives, healthy volunteers, and even with idiopathic pulmonary fibrosis patients $(4,5)$.

The present study confirmed that high levels of IgG and IgAAA were more frequently positive in the PBD group than in healthy controls with no history of avian exposure, and also exceeded the levels of asymptomatic pigeon breeders. Interestingly, the most significant serological abnormality in PBD patients was the presence of high IgAAA levels in agreement to previous studies (5).

The literature reports that few studies of the presence of IgM AA in PBD and its clinical and pathological significance have been examined (6-8). We detected high levels of IgM AA in sera from definite PBD patients by ELISA that occurred in both the positive and negative precipitating AA groups. The presence of elevated IgM levels was more common in PBD in comparison to healthy controls not exposed to avian antigens, the levels also differed from those values detected in asymptomatic pigeon breeders.

The use of Western blot confirmed the positive reaction of IgM AA in PBD against a 58-kDA polypeptide and although it did not occur in healthy controls, we also detected similar results in asymptomatic pigeon breeders.

Previous studies regarding AA included anecdotal reports of high levels of IgM AA by RIA in PBD patients with severe acute disease, followed by a decrease of those titers after the cessation of antigen exposure and corticosteroid therapy (8). The presence of IgMAA in PBD in some reports has also been detected by enzyme-linked immunofiltration assays $(16,17)$.

In other studies, positive IgM AA by radioimmunoelectrophoresis occurred in 10 out of 16 patients with budgerigar fancier's lung, whereas only 2 positive IgM sera were 
found in 29 subjects exposed to budgerigars who developed respiratory diseases other than hypersensitivity pneumonitis (18). IgM antibody activity against Trichosporon cutaneum has also been found by ELISA in 17\% of summer-type hypersensitivity pneumonitis (19). Finally, experimental models of lung hypersensitivity have noted the appearance of IgM antibodies early in the development of the disease (20).

The simultaneous presence of different immunoglobulins against avian antigen in our PBD group is in agreement with the reports of other groups that $\operatorname{IgM}$ together with $\operatorname{IgG}$ and $\operatorname{Ig} \mathrm{A}$ AA may occur in clinically ill pigeon breeder's subjects $(16,17)$.

We detected no unique or consistent factors which may explain the presence of IgM AA, nevertheless, several factors such as variation in the kind of antigen, length time of exposure, smoking habit, and immunogenetic background have been linked to other specific immunological findings in PBD (21).

It has been reported that levels of IgG and IgA AA consistently declined, whereas IgM values may demonstrate a gradual rise during the evolution of the disease (17). Positive IgM AA by RIA have been reported in PBD patients with a previous history of allergy, acute intermittent attacks of respiratory symptoms, and continuing exposure to pigeons (17). The appearance of IgM AA associated with a recent antigen challenge and an acute disease in our PBD group is similar to the results of earlier studies (8) and may be useful for diagnostic purposes.

Additionally, the PBD results are also compatible with the persistence of antigen exposure during subacute and chronic disease. In this sense, a decrease in IgG AA may occur in pigeon breeders who had discontinued their hobby, but a persistence of high levels of these antibodies have been observed after repeated antigen challenge (22). The long-lasting history of keeping pigeons detected in some PBD patients may perpetuate the immunological response and a persistent antigen contact may stimulate recurrent IgM synthesis. This antibody production may depend also on the degree of local or systemic inflammatory reaction after the antigen challenge (23).

It is of interest that some laboratories have proposed less interference in detecting $\operatorname{IgM}$ due to the $\operatorname{IgG}$ and $\operatorname{IgA}$ decrease in serum samples. False negative results were also described by some authors in sera that had been thawed/frozen several timessuch treatment makes it difficult to evaluate the presence and titers of IgM AA, since complex formation followed precipitation and/or degradation of IgM may reduce those levels.

In addition to the diagnostic value, the presence of $\operatorname{IgM}$ AA may be associated with a pathological role (24). IgM AA antibodies in sera and BAL fluid have been reported in the acute stage of PBD (22). High levels of total IgM in BAL from chronic hypersensitivity pneumonitis patients, as well as an increase of antigen specific IgM antibodies in lung tissue from PBD also have been detected (25-27). In this sense, IgM AA may participate in the immune complexes formation and deposition within the lung, where neutrophil accumulation along with activated components of complement take place.
Studies of specific lymphocyte activation in CD5 B cells that produce $\operatorname{IgM}$ and the analysis of Th2 cell cooperation during the persistence of antibody response in PBD are now in progress in our laboratory.

\section{ACKNOWLEDGMENTS}

This work was partially funded by grants from the National Council of Science and Technology (CONACYT), Mexico (D111-903735 and F643-M9406).

\section{REFERENCES}

1. Selman M, Terán L, Mendoza A, et al. Increase of HLA DR7 in pigeon breeder's lung in a Mexican population. Clin Immunol Immunopathol 1987;44:63-70.

2. Kitt S, Woo CL, Fink JN, Calvanico NJ. Immunoglobulin G4 in pigeon breeder's disease. J Lab Clin Med 1986;108:442-447.

3. Bourke S, Anderson K, Lynch P, et al. Chronic bronchitis in pigeon fanciers. Relationship of cough with expectoration to avian exposure and pigeon breeder's disease. Chest 1989;95:598-601.

4. Mendoza F, Baltazares M, Ramírez A, et al. Detection of salivary and seric $\operatorname{IgG}$ and $\operatorname{IgA}$ antipooled pigeon sera activities in patients with pigeon breeder's disease. J Clin Lab Anal 1996;10:149-154.

5. Patterson R, Wang JLF, Fink JN, Calvanico NJ, Roberts M. IgA and IgG antibody activities of serum and bronchoalveolar fluid from symptomatic and asymptomatic pigeon breeders. Amer Rev Res Dis 1979;120:1113-1118.

6. Yoshizawa Y, Mirake S, Sumi Y, Hisauchi K, Sato T, Kurup VP. A follow-up study of pulmonary function tests, bronchoalveolar lavage cells and humoral and cellular immunity in bird fancier's lung. J Allergy Clin Immunol 1995;96:122-129.

7. Yoshizawa Y, Ohtani Y, Inoue T, et al. Immune response to inhaled antigens local antibody production in the respiratory tract in healthy and lung disease. Clin Exp Immunol 1995;100:395-400.

8. Patterson R, Schatz M, Fink JN, De Swarte RS, Roberts M, Cugell D. Pigeon breeder's disease. I. Serum concentrations; IgG, IgM, IgA, IgE antibodies against pigeon serum. Am J Med 1976;60:144-155.

9. Sansores RH, Selman M, Martínez-Cordero E, et al. Bronchoalveolar and serum elevated levels of beta-2 microglobulin in patients with hypersensitivity pneumonitis. Med Sci Res 1988;16:403-404.

10. Martínez-Cordero E, Bessudo Babani A, Treviño-Pérez SC, Terán L, Selman M, Martínez-Miranda E. Circulating autoantibodies in patients with pigeon breeder's disease. Allergol Immunopathol 1989;17:1-6.

11. Fink JN. Disease of the lung. In: Rose NR, Friedman H, Fahey JL, editors. Manual of clinical laboratory immunology. Washington, D.C.: American Society of Microbiology; 1986. p 698-701.

12. Ezaki Y, Shingu M, Nobunaga M, Otsuka E. Detection of low molecular weight IgM by immunoblot analysis in rheumatoid arthritis. J Rheumatol 1987;14:674-679.

13. Laemmli UK. Cleavage of structural proteins during the assembly of the head of bacteriophage T4. Nature 1970;227:680-685.

14. Towbin H, Staehelin T, Gordon J. Electrophoretic transfer of proteins from polyacrilamide gels to nitrocellulose sheet: procedure and some applications. Proc Natl Acad Sci U S A 1979;76:4350-4354.

15. Martínez-Cordero E, Negrete-García MC, MendozaA. Rheumatoid factor activity in serum and bronchoalveolar lavage from patients with acute hypersensitivity pneumonitis. J Invest Allergol Clin Immunol 1992;2:254-257.

16. Pinon JM, Geers R, Lepan H, Pailler S. Immunodetection by enzyme linked immunofiltration assay (ELIFA) of $\operatorname{IgG}, \operatorname{IgM}, \operatorname{IgA}$ and IgE antibodies in bird breeder's disease. Eur J Respir Dis 1987; 71:164-169. 
17. Patterson R, Harris KE, Pruzansky JJ, Zeiss CR. An animal model of occupational immunologic asthma due to diphenylmethane diisocyanate, with multiple systemic immunologic responses. J Lab Clin Med 1982;99:615-623.

18. Faux JA, Wide L, Hargreave FE, Longbottom JL, Pepys J. Immunological aspects of respiratory allergy in budgerigar (Melopsittacus undulatus) fanciers. Clin Allergy 1971;1:149-158.

19. Soda K, Ando M, Shimazu K, Sakata T, Yoshida K, Araki S. Different classes of antibody activities to Trichosporon cutaneum antigen in summer-type hypersensitivity pneumonitis by enzyme-linked immunosorbent assay. Am Rev Resp Dis 1986;133:83-87.

20. Wilkie BN, Nielsen KH, Little J. Experimental hypersensitivity pneumonitis: serum immunoglobulins G1, G2, MA and E in Micropolyspora faeni sensitized and desensitized calves. Int Arch Allergy Appl Immunol 1978;56:79-86.

21. McSharry C, Banham SW, Boyd G. Effect of cigarette smoking on the antibody response to inhaled antigens and the prevalence of extrinsic allergic alveolitis among pigeon breeders. Clin Allergy 1985;15:487-494.
22. Bourke SJ, Banham SW, Carter R, Lynch P, Boyd G. Longitudinal course of extrinsic allergic alveolitis in pigeon breeders. Thorax 1989;44:418-428.

23. Yoshizawa Y, Ohtani Y, Inove T, et al. Immune responsiveness to inhaled antigens: local antibody production in the respiratory tract in health and lung diseases. Clin Exp Immunol 1995;100:395-400.

24. Huizinga M, Lubbers M, Berrens L. Detection of precipitating and complement consuming antibodies by enzyme linked immunosorbent assay in pigeon breeder's disease. Immunobiology 1984;166:168-176.

25. Weinberger SE, Kelman JA, Elson NA, et al. Bronchoalveolar lavage in interstitial lung disease. Ann Intern Med 1978;89:459-466.

26. Reynolds HY, Fulmer JD, Kazmierowski JA, Roberts WC, Frank MM, Crystal RG. Analysis of cellular and protein content of bronchoalveolar lavage fluid from patients with idiopathic pulmonary fibrosis and chronic hypersensitivity pneumonitis. J Clin Invest 1977;59:165-175.

27. Popp W, Braun O, Zwick H, Rauscher H, Ritschka L, Flicker M. Detection of antigen specific antibodies on lung tissue in a patient with hypersensitivity pneumonits. Virchows Arch A Pathol Anat Histopathol 1988;413:223-226. 